\title{
Mechanism of High-level Resistance to Chloramphenicol in Different Escherichia coli Variants
}

\author{
By D. SOMPOLINSKY AND ZEMIRA SAMRA \\ Rapaport Laboratories for Microbiology, \\ Bar-Ilan University, Ramat Gan, \\ and Department for Microbiology, Assaf Harofe \\ Government Hospital, Zrifin, Israel
}

(Accepted for publication I July 1967)

\begin{abstract}
SUMMARY
Mutants resistant to high levels of chloramphenicol can be obtained in Escherichia coli B by one or two mutational events. All of I 44 high-level resistant mutant clones examined were powerful inactivators of the drug. Growth of this kind of mutants in nutrient media containing chloramphenicol I $00 \mu \mathrm{g}$. $/ \mathrm{ml}$. or more depended on the inoculum size, the composition of the medium, and the concentration of the drug. No growth was observed with lactose as sole energy source unless the organisms had been previously induced for $\beta$-galactosidase production.

With a strain of Escherichia coli $\mathrm{K} 12$ an entirely different type of resistant mutants occurred. High-level resistant derivatives were obtainable only through several serial mutations. None of 36 high-level resistant mutants was able to inactivate the drug. Growth of these bacteria was extremely slow, even in the absence of drug. This resistance was due to a decreased rate of permeation, which probably was non-specific and concerned many species of micromolecules.
\end{abstract}

\section{INTRODUCTION}

Resistance to chloramphenicol may be due to different mechanisms: (I) resistance of the protein synthesizing machinery (Ramsey, I958); (2) decreased permeation to the site of antibiotic action (Cavalli \& Maccacaro, I952; Okamoto \& Mizuno, I962, I964; Vazquez, I963, I964); (3) inactivation of the drug (Okamoto \& Suzuki, I965; Rananarayna, Rayaulakshmi \& Ehaskaran, 1962; Miyamura, 1964; Chabbert \& Debruge, I956; Dunsmoor, Pin \& Sherris, 1963).

Studies with Escherichia coli B and E. coli $\mathrm{K}$ I2 have now shown that high-level resistance to chloramphenicol in $E$. coli B is due to inactivation and in $E$. coli $\mathrm{K}$ I2 to impaired permeation. Inactivation of chloramphenicol has been effected also with the susceptible wild-type $E$. coli $\mathrm{B}$, though at a slow rate, but could not be demonstrated with $E$. coli $\mathrm{K} \mathrm{I2}$. This is apparently a parallel to the well-known fact that penicillinase-producing mutants are never obtained from initially penicillinase-negative bacterial strains.

\section{METHODS}

Bacterial strains. (I) Escherichia coli в: the wild strain was inhibited on nutrient agar containing chloramphenicol $(\mathrm{cm}) 2.5 \mu \mathrm{g}$. $/ \mathrm{ml}$.; for the present work a mutant resistant to dihydrostreptomycin $5000 \mu \mathrm{g} . / \mathrm{ml}$. and sulphathiazole $40 \mu \mathrm{g} . / \mathrm{ml}$. was developed; 
Cm-resistant mutants isolated were tested for dihydrostreptomycin and sulphathiazole resistance. (2) E. coli K I2-W 945 (lactose-, proline-, thiamine-): this strain was inhibited by $\mathrm{Cm} 4.0 \mu \mathrm{g} . / \mathrm{ml}$. (3) $E$. coli $\mathrm{K} \mathrm{I2-W} \mathrm{945:} \mathrm{with} \mathrm{resistance} \mathrm{transfer} \mathrm{factor}$ (RTF) mediating resistance to dihydrostreptomycin, sulphathiazole, tetracycline and chloramphenicol. The RTF was transferred from a wild strain of Shigella flexneri by using the technique of Watanabe \& Fukasawa, 196r. (4) A susceptible wild strain of Shigella boydii was used for assay of chloramphenicol concentrations.

Drugs. Chloramphenicol (Cm) was obtained from Abic Ltd., Ramat-Gan, Israel. $\left[{ }^{14} \mathrm{C}\right] \mathrm{Cm}$ (methylene- ${ }^{14} \mathrm{C}$ ) was purchased from The Radiochemical Centre, Amersham, Buckinghamshire, England; its activity was stated to be $6.8 \mathrm{I} \mathrm{mc} / \mathrm{mm}$. Tetracycline $\mathrm{HCl}$ : Lederle.

Culture media. (I) Bacto blood agar base (BAB). (2) Bacto tryptose phosphate broth (TP): same solidified with $\mathrm{I} \cdot 5 \%$ Bacto agar is designated TPA. (3) Davis's minimal medium (Davis \& Mingioli, 1950) and the same solidified with Bacto Noble Agar are designated DB and DA, respectively. The same minimal media were also used with lactose substituted for glucose (lactose DB, lactose DA). For growth of Escherichia coli K I2-W 945, the minimal medium was supplemented with L-proline $50 \mathrm{mg}$. and thiamine $\mathrm{HCl}$ I $\mathrm{mg}$. per litre.

Mutation rate was estimated by the method of Luria \& Delbrück (1943). In each experiment 20-56 independent cultures grown overnight from an inoculum of about I00 bacteria were plated on $\mathrm{DA}$ or $\mathrm{BAB}$ with $\mathrm{Cm}$. The mutation rate was calculated from the fraction of clones with no mutants.

Bioassay for chloramphenicol. The samples to be tested were sterilized by heating in a boiling water bath during $5 \mathrm{~min}$. This procedure stopped the enzymic activity. Control samples showed no decrease in the activity of chloramphenicol due to the heating. For chloramphenicol $(\mathrm{Cm})$ assay, a susceptible strain of Shigella boydii was used as indicator. Samples of the test samples heated to $37^{\circ}$ were added to cultures in the exponential phase $\left(\mathrm{I} \cdot 7 \times 10^{8}-2 \cdot \mathrm{I} \times 10^{8}\right.$ bacteria $/ \mathrm{ml}$.). The amount added was calculated to give a final concentration of $\mathrm{Cm} 2 \mu \mathrm{g}$. $/ \mathrm{ml}$. if no inactivation of the drug had taken place. Turbidity of the cultures was examined with a Klett Summerson photoelectric colorimeter every $20 \mathrm{~min}$. during I hr. Control cultures of $S$. boydii in TP medium with $\mathrm{Cm}$ were included in each titration. The following concentrations of $\mathrm{Cm}(\mu \mathrm{g} . / \mathrm{ml}$.) were used in these controls: $0,0.5,1 \cdot 0,2 \cdot 0$. From these controls a curve of generation time as a function of $\mathrm{Cm}$ concentration was drawn. The $\mathrm{Cm}$ concentration in the test samples was then determined from the generation time by interpolation.

Uptake of $\left[{ }^{14} \mathrm{C}\right] \mathrm{Cm}$. An exponential culture in TP medium was gathered by centrifugation to a concentration of $4 \times 10^{10}$ bacteria $/ \mathrm{ml}$. and $\left[{ }^{14} \mathrm{C}\right] \mathrm{Cm} 2 \mu \mathrm{g} . / \mathrm{ml}$. added. The culture was incubated with slight shaking during $20 \mathrm{~min}$. at $37^{\circ}$, chilled, and the bacteria washed twice with $2 \mathrm{ml}$. cooled plain TP medium and once with $2 \mathrm{ml}$. distilled water. After the last deposition of the bacteria by centrifugation, I $\mathrm{ml}$. of the supernatant liquid was transferred into a counting vial, and so was the sediment after resuspension. To each sample was added $15 \mathrm{ml}$. of following scintillator: 6 g. 2,5diphenyloxazole, $0 \cdot 3 \mathrm{~g}$. I,4-bis-2-(5-phenyloxazolyl)-benzene + $100 \mathrm{~g}$. naphthalene in I 1. $p$-dioxane. The vials were counted in a Packard Tricarb liquid scintillation spectrometer, model 3203 . The radioactivity of the intercellular fluid varied between $15 \%$ and $25 \%$ of the activity of the cell suspension. Uptake of $\mathrm{Cm}$ by the bacteria was calculated from the difference between radioactivity of the cell suspension and 
the intercellular fluid. Results were compared with radioactivity obtained by arbitrary amounts of $\left[{ }^{14} \mathrm{C}\right] \mathrm{Cm}$ added to vials of bacteria treated as the test samples but without added $\mathrm{Cm}$.

Results were correlated to the wet weight of bacteria, which was determined by centrifugation at $18,000 \mathrm{~g}$ for $10 \mathrm{~min}$., removing the supernatant fluid and draining by tilting the test-tube on adsorbing paper. One g. wet Escherichia coli в corresponded to $6 \cdot 8 \times 10^{11}$ bacteria.

\section{RESULTS}

\section{Escherichia coli B mutants}

Mutation rate was determined in five different experiments using media BAB and DA containing $\mathrm{Cm} 4^{\circ} \circ \mu \mathrm{g}$. $/ \mathrm{ml}$. The results varied between $5.3 \times 10^{-10}$ and $6.7 \times 10^{-9}$ mutations/bacterium/division. The degree of resistance was determined for 635 separate mutant colonies. The mutant clones were first purified by several transfers on agar medium containing $\mathrm{Cm} 4 \mu \mathrm{g}$. $/ \mathrm{ml}$. Heavy suspensions in broth were then streaked on BAB containing different $\mathrm{Cm}$ concentrations. Of the clones 578 were inhibited by $\mathrm{Cm} 8 \mu \mathrm{g}$. $/ \mathrm{ml}$., $2 \mathrm{I}$ clones by I $6 \mu \mathrm{g} . / \mathrm{ml}$., and 36 clones $(5 \cdot 7 \%)$ by $\mathrm{I} 50-300 \mu \mathrm{g} . / \mathrm{ml}$.

One-step high-level resistant mutants were obtained more conveniently by plating the susceptible strain on $\mathrm{BAB}$ containing $\mathrm{Cm} \mathrm{I} 6 \mu \mathrm{g}$. $/ \mathrm{ml}$. The mutation rate was in this case calculated to be $\mathrm{I} \cdot 2 \times \mathrm{IO}^{-10}$ mutations/bacterium/division. Of 100 mutant clones examined 100 grew when streaked on BAB with $\mathrm{Cm} 100 \mu \mathrm{g} . / \mathrm{ml}$. and 8 on $250 \mu \mathrm{g} . / \mathrm{ml}$. High-level resistant mutants were also isolated from low-level resistant clones $(\mathrm{Cm} 4 \mu \mathrm{g} . / \mathrm{ml}$.) by plating on BAB with $\mathrm{Cm} 16 \mu \mathrm{g} . / \mathrm{ml}$. These mutations occurred at a frequency of about $10^{-9} / \mathrm{bacterium} /$ division. It might be concluded from these experiments that Escherichia coli B may obtain low-level as well as highlevel resistance to chloramphenicol in a single mutational event.

Inactivation of chloramphenicol by Escherichia coli в. The susceptible Escherichia coli B inactivates chloramphenicol but at a very slow rate. This was shown in experiments of the following type. A TP culture was grown to the exponential growth phase and the bacteria concentrated by centrifugation to a density of $\mathrm{I} \cdot 6 \times \mathrm{IO}^{9}$ bacteria/ $\mathrm{ml}$. Chloramphenicol was added to $\mathrm{Cm} 100 \mu \mathrm{g} . / \mathrm{ml}$. and the culture incubated for $\mathrm{I} 8 \mathrm{hr}$ at $37^{\circ}$. Assay of residual $\mathrm{Cm}$ showed about $80 \mu \mathrm{g}$. $/ \mathrm{ml}$.

On the other hand, II4 one-step and 30 two-step high-level resistant clones all proved to be powerful inactivators of $\mathrm{Cm}$. In the tests with these strains, TP with $\mathrm{Cm} 100 \mu \mathrm{g} . / \mathrm{ml}$. was inoculated with about $2.0 \times 10^{8}$ bacteria $/ \mathrm{ml}$. After $\mathrm{I} 8 \mathrm{hr}$ incubation at $37^{\circ}$ and centrifugation the supernatant culture fluid was assayed for $\mathrm{Cm}$; none was found.

The kinetics of $\mathrm{Cm}$ inactivation were studied more closely in a few of the one-step high-level resistant clones. Some observations with one of the strains (Escherichia coli $\mathrm{B} / \mathrm{I}$ ) will be given. After addition of $\mathrm{Cm}$ to $100 \mu \mathrm{g} . / \mathrm{ml}$. to an exponentially growing culture of $E$. coli $\mathrm{B} / \mathrm{I}$ in TP, more than $90 \%$ of the $\mathrm{Cm}$ was inactivated during $30 \mathrm{~min}$. and inactivation was complete after $60 \mathrm{~min}$. (Fig. I). At this time the growth, which initially was slowed by the $\mathrm{Cm}$, continued at the same rate as in the control culture. With $\mathrm{Cm} 400 \mu \mathrm{g}$. $/ \mathrm{ml}$., $75 \%$ of the $\mathrm{Cm}$ was inactivated in $30 \mathrm{~min}$, and after $120 \mathrm{~min}$. inactivation was complete; however, even then growth remained slow (Fig. 2). This problem will be dealt with elsewhere.

Inoculum size and nutrient medium. The minimal inhibitory concentration of $\mathrm{Cm}$ 
for Escherichia coli $\mathbf{B} / \mathrm{I}$ depends on the inoculum size and the nutrient medium. This is shown by observations summarized in Table I. An exponential phase culture in TP was centrifuged, the bacteria washed twice in cold phosphate buffer $\left(\mathrm{pH}_{7} \cdot 2\right.$; $0.15 \mathrm{M}$ ) and inoculated on plain TPA as well as on TPA containing various amounts of $\mathrm{Cm}$. With $\mathrm{Cm}$ up to $60 \mu \mathrm{g}$. $/ \mathrm{ml}$. the colony counts were as on plain agar. However, with TPA containing $\mathrm{Cm} 100 \mu \mathrm{g}$. $/ \mathrm{ml}$. growth occurred only when at least $9 \times 10^{3}$ bacteria were seeded, but then growth was confluent as on the control plate with

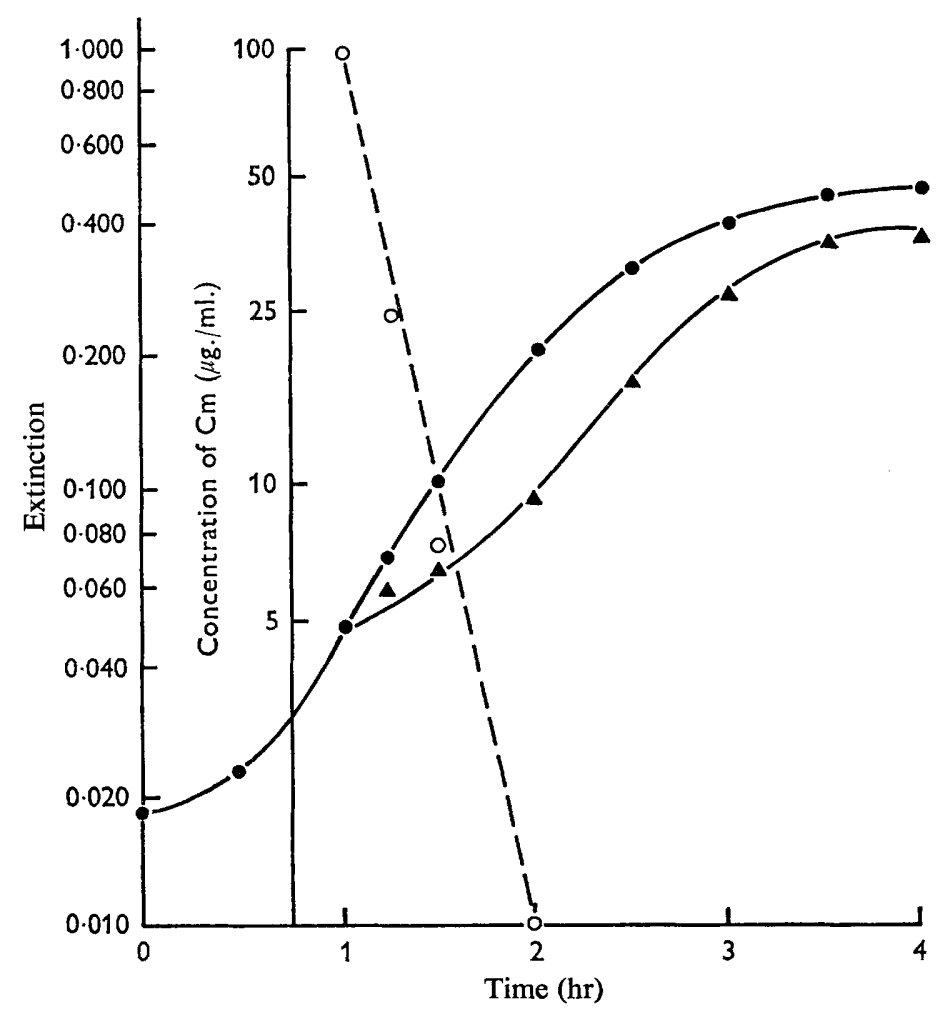

Fig. I. Inactivation of chloramphenicol by Escherichia coli $\mathrm{B} / \mathrm{I}$ and growth in tryptose phosphate medium (TP) with and without $\mathrm{Cm} 100 \mu \mathrm{g} . / \mathrm{ml}$. Extinction and concentration of residual chloramphenicol are plotted on logarithmic scales against a linear time scale. $\mathrm{O}-\mathrm{O}, \mathrm{Cm}$ concentration; - - , growth of strain $\mathrm{B} / \mathrm{r}$ without $\mathrm{Cm} ; \boldsymbol{\Delta}-\boldsymbol{\Delta}$, growth in presence of $\mathrm{Cm} 100 \mu \mathrm{g} . / \mathrm{ml}$.

a similar inoculum. To obtain growth on TPA with $\mathrm{Cm} 200 \mu \mathrm{g} . / \mathrm{ml}$. a 1000-fold increase in inoculum size (to $9 \times 10^{6}$ ) was required. With this inoculum growth was confluent, though no colonies occurred on the plate inoculated with $9 \times 10^{5}$ bacteria. On minimal medium with glucose (DA) an inoculum size of $9 \times 10^{6}$ was required for growth in $\mathrm{Cm} 100 \mu \mathrm{g} . / \mathrm{ml}$.

Of special interest was the observation that on lactose $\mathrm{DA}+\mathrm{Cm} 100 \mu \mathrm{g} . / \mathrm{ml}$. no growth was obtained even with an inoculum of $9 \times 10^{7}$ bacteria $/ \mathrm{ml}$. However, when the galactosidase-system was induced by incubation with lactose ( $\mathrm{r} \mathrm{hr}$ ), no difference was observed between growth on lactose and glucose media.

Uptake of $\left[{ }^{14} \mathrm{C}\right] \mathrm{Cm}$. No significant difference was noticed in the uptake of labelled 
chloramphenicol between Escherichia coli в and its high-level resistant derivative E. coli $\mathrm{B} / \mathrm{I}$ (Table 2 ). The radioactivity/g wet wt bacteria corresponded very closely to the $\left[{ }^{14} \mathrm{C}\right] \mathrm{Cm} 2 \mu \mathrm{g}$. $/ \mathrm{ml}$. initially added to the suspension of the bacteria. Even though a part of the reversibly bound $\mathrm{Cm}$ might have been removed by washing, it seems that no marked intracellular concentration of label had taken place, and this in spite of the fact that with the high bacterial concentration used $\left(4 \times \mathrm{I}^{10}\right.$ bacteria/ml.) virtually all the $\mathrm{Cm}$ must have been inactivated (compare Fig. I). It seems therefore

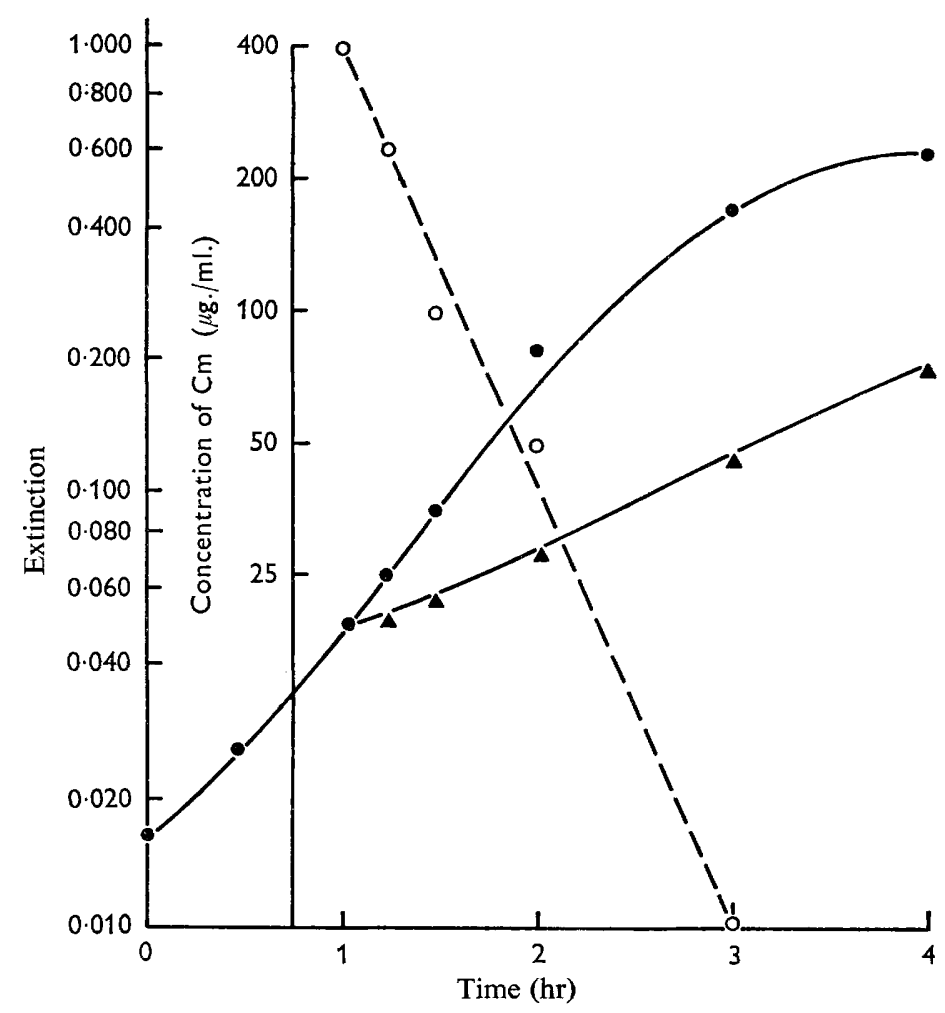

Fig. 2. Inactivation of chloramphenicol by Escherichia coli $\mathrm{B} / \mathrm{I}$ and growth in tryptose phosphate broth medium with and without $\mathrm{Cm} 400 \mu \mathrm{g} . / \mathrm{ml}$. O---O, Residual $\mathrm{Cm}$; growth without $\mathrm{Cm} ; \boldsymbol{\Delta}-\mathbf{\Delta}$, growth in presence of $\mathrm{Cm}$.

that the turnover of $\mathrm{Cm}$ molecules was high, so that after $20 \mathrm{~min}$. the same amount of radioactivity was found in the susceptible bacteria as in those which had inactivated about 17 times more $\mathrm{Cm}$ than the amount corresponding to the amount of label found.

Cross resistance to tetracycline. No resistance to tetracycline was found in 22 onestep high-level resistant mutants of Escherichia coli в. The minimal inhibitory concentration in BAB of tetracycline was I $\mu \mathrm{g}$./ml., both for the mutants and for the susceptible ancestor.

\section{Escherichia coli $\mathrm{K} I 2$ mutants}

Mutants were isolated by plating on BAB and DA containing chloramphenicol 8-16 $\mu \mathrm{g}$. $/ \mathrm{ml}$. Mutation rate varied in different experiments between $4.6 \times 10^{-10}$ and 
$\mathrm{I} \cdot 3 \times 1 \mathrm{I}^{-9}$ mutations/bacterium/division. High-level resistance was only obtained stepwise. Four mutational events were needed for resistance to $\mathrm{Cm} 300 \mu \mathrm{g} . / \mathrm{ml}$.

Inactivation of chloramphenicol. Inactivation by the susceptible Escherichia coli $\mathrm{x}$ I 2 was examined on a TP culture concentrated to about $1 \cdot 6 \times 10^{9}$ bacteria $/ \mathrm{ml}$. and

Table I. Minimal inhibitory concentration of chloramphenicol for Escherichia coli $B / I$ : the effects of inoculum size and growth medium

Incubation was for $48 \mathrm{hr}$ at $37^{\circ}$.

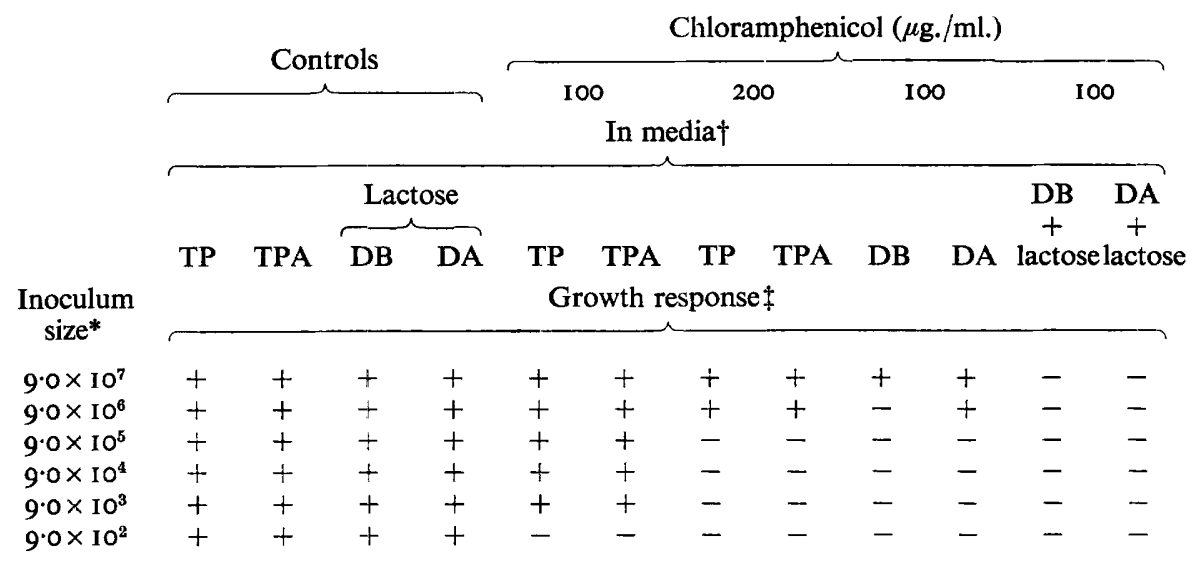

* No. of viable bacteria inoculated per tube (Io ml. liquid medium) or per plate (ro ml. solid medium) and distributed evenly on the surface by a cotton-wool applicator.

$\dagger \mathrm{TP}=$ Tryptose phosphate broth; TPA = same solidified with agar; $\mathrm{DB}=$ minimal medium; lactose $\mathrm{DB}=$ same with lactose substituted for glucose; DA and lactose DA = same solidified with agar.

$\ddagger$ Growth response: + , in tube, pronounced turbidity; on Petri dish, confluent growth; - , no growth.

Table 2. Uptake of $\left[{ }^{14} \mathrm{C}\right]$ chloramphenicol by various strains of Escherichia coli

\begin{tabular}{|c|c|c|c|c|c|c|c|c|}
\hline \multirow[b]{2}{*}{$\begin{array}{c}\text { Sample } \\
\text { no. }\end{array}$} & \multicolumn{2}{|c|}{ E. coli $\mathrm{B}$} & \multicolumn{2}{|c|}{ E. coli $\mathrm{B} / \mathrm{I}$} & \multicolumn{2}{|c|}{ E. coli $\mathrm{K} \mathbf{I} 2$} & \multicolumn{2}{|c|}{ E. coli $\mathrm{K} \mathrm{I} 2 / \mathrm{I}$} \\
\hline & $\begin{array}{l}\text { CPM*/ } \\
59 \text { mg. } \dagger \\
\text { bacteria }\end{array}$ & $\begin{array}{c}\mu \text { g. } \mathrm{Cm} \ddagger / \\
\text { g. } \\
\text { bacteria }\end{array}$ & $\begin{array}{c}\text { CPM/ } \\
59 \mathrm{mg} . \\
\text { bacteria }\end{array}$ & $\begin{array}{c}\mu \mathrm{g} . \mathrm{Cm} / \\
\mathrm{g} . \\
\text { bacteria }\end{array}$ & $\begin{array}{c}\text { CPM/ } \\
59 \mathrm{mg} . \\
\text { bacteria }\end{array}$ & $\begin{array}{c}\mu \mathrm{g} . \mathrm{Cm} / \\
\text { g. } \\
\text { bacteria }\end{array}$ & $\begin{array}{r}\text { CPM/ } \\
59 \mathrm{mg} . \\
\text { bacteria }\end{array}$ & $\begin{array}{c}\mu \mathrm{g} . \mathrm{Cm} / \\
\mathrm{g} . \\
\text { bacteria }\end{array}$ \\
\hline I & 6080 & $2 \cdot I$ & 5815 & $2 \cdot 0$ & $946 \mathrm{I}$ & $3 \cdot 2$ & 1701 & 0.58 \\
\hline 2 & 5297 & I. 8 & 4334 & $\mathrm{I} \cdot 5$ & 9141 & $3 \cdot I$ & 1426 & 0.49 \\
\hline 3 & $5 I 44$ & $\mathrm{I} \cdot 8$ & . & . & 8614 & $2 \cdot 9$ & 1320 & 0.45 \\
\hline
\end{tabular}

* CPM, counts/min.

† All weights are wet weight determined for cultures of the same turbidity values as the samples.

¥Chloramphenicol $(\mathrm{Cm})$ calculated by comparison with $\mathrm{CPM}$ obtained with $0 \cdot 1 \mu \mathrm{g}$. $\left.{ }^{14} \mathrm{C}\right] \mathrm{Cm}$ in $59 \mathrm{mg}$. E. coli.

addition of $\mathrm{Cm}$ to $100 \mu \mathrm{g} . / \mathrm{ml}$. In 36 high-level resistant derivatives inactivation was examined by growing cultures in TP with $\mathrm{Cm} 100 \mu \mathrm{g} . / \mathrm{ml}$. After $24-28 \mathrm{hr}$ virtually the entire amount of added $\mathrm{Cm}$ was found on assay (95-105\%). It was therefore concluded that neither the susceptible ancestor nor its resistant mutants were able to inactivate chloramphenicol. 
Properties of high-level resistant mutants. Determination of viable counts of the high-level resistant cultures on plain TPA and on TPA+chloramphenicol gave comparable results. The inoculum size was of no influence on the minimal inhibitory concentration $(\mathrm{Cm} 350 \mu \mathrm{g} . / \mathrm{ml}$.). The markers L-proline, thiamine and lactose were unaltered in the resistant mutants, but the bacteria were more elongated with $2 \cdot 7$ nuclei/bacterium in an early exponential phase culture instead of $I \cdot 4$ nuclei/bacterium

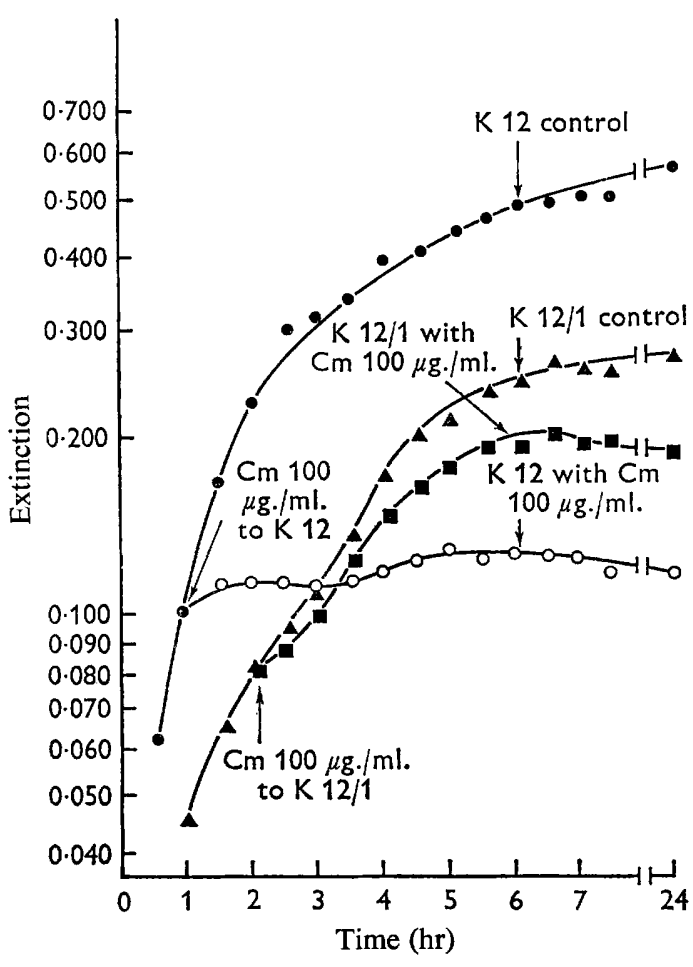

Fig. 3

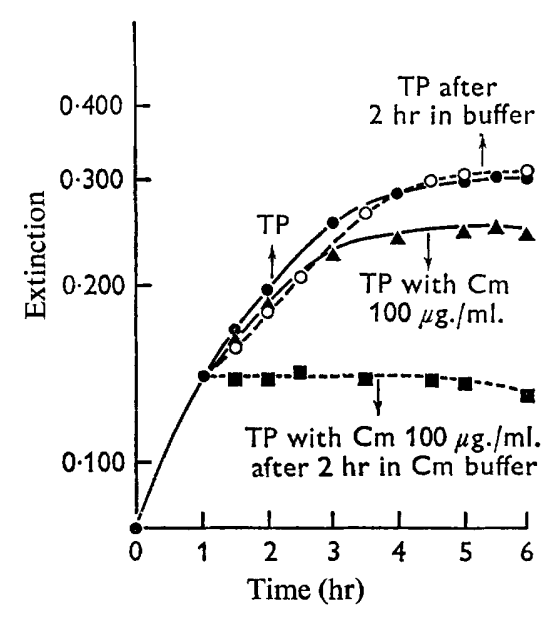

Fig. 4

Fig. 3. Comparison of growth of Escherichia coli $\mathrm{K} \mathrm{I} 2$ and its resistant mutant E. coli $\mathrm{K}$ I2/I in tryptose phosphate broth medium, with and without chloramphenicol $(\mathrm{Cm})$.

Fig. 4. Inhibition of growth of Escherichia coli $\mathrm{K} \mathrm{I2/1}$ after pre-incubation in a buffer solution containing chloramphenicol $(\mathrm{Cm})$ I00 $\mu \mathrm{g} . / \mathrm{ml} .,---$; without pre-incubation - -

in the susceptible parent strain. All the resistant mutants examined grew very slowly on plain nutrient media as well as on Cm-containing media. In Fig. 3, growth in TP ( $37^{\circ}$, with shaking) of the susceptible strain is compared with growth of one of the high-level resistant mutants (Escherichia coli $\mathrm{K} \mathrm{I} / \mathrm{I}$ ). The shortest generation time was about $30 \mathrm{~min}$. for the susceptible and $100 \mathrm{~min}$. for the resistant strain. Growth ceased at 0.52 extinction for the susceptible strain as compared with only 0.28 for the resistant strain. Addition of $\mathrm{Cm} 100 \mu \mathrm{g} . / \mathrm{ml}$. to the culture of the resistant strain had almost no effect during the first $90 \mathrm{~min}$; thereafter the growth slowed down to cease entirely at 0.20 extinction. This might indicate that 'resistance' in $E$. coli $\mathrm{K} \mathrm{I2/I}$ was caused by decrease in the permeability of the bacteria to the drug. This assumption was confirmed when the bacteria were suspended in a buffer 
solution containing $\mathrm{Cm} 100 \mu \mathrm{g} . / \mathrm{ml}$. during $\mathrm{I} 20 \mathrm{~min}$. before incubation in $\mathrm{Cm}+\mathrm{TP}$ medium. Inhibition of growth was in this case immediate and complete (Fig. 4).

Escherichia coli $K I 2$ infected with resistance transfer factor $(R T F)$. Further evidence for the assumption that permeation by chloramphenicol was delayed in $E$. coli $\mathrm{K} \mathrm{I} 2 / \mathrm{I}$ was obtained by infecting this strain as well as its ancestor $(E$. coli $\mathrm{K} 12)$ with a resistance transfer factor from a strain of Shigella flexneri.

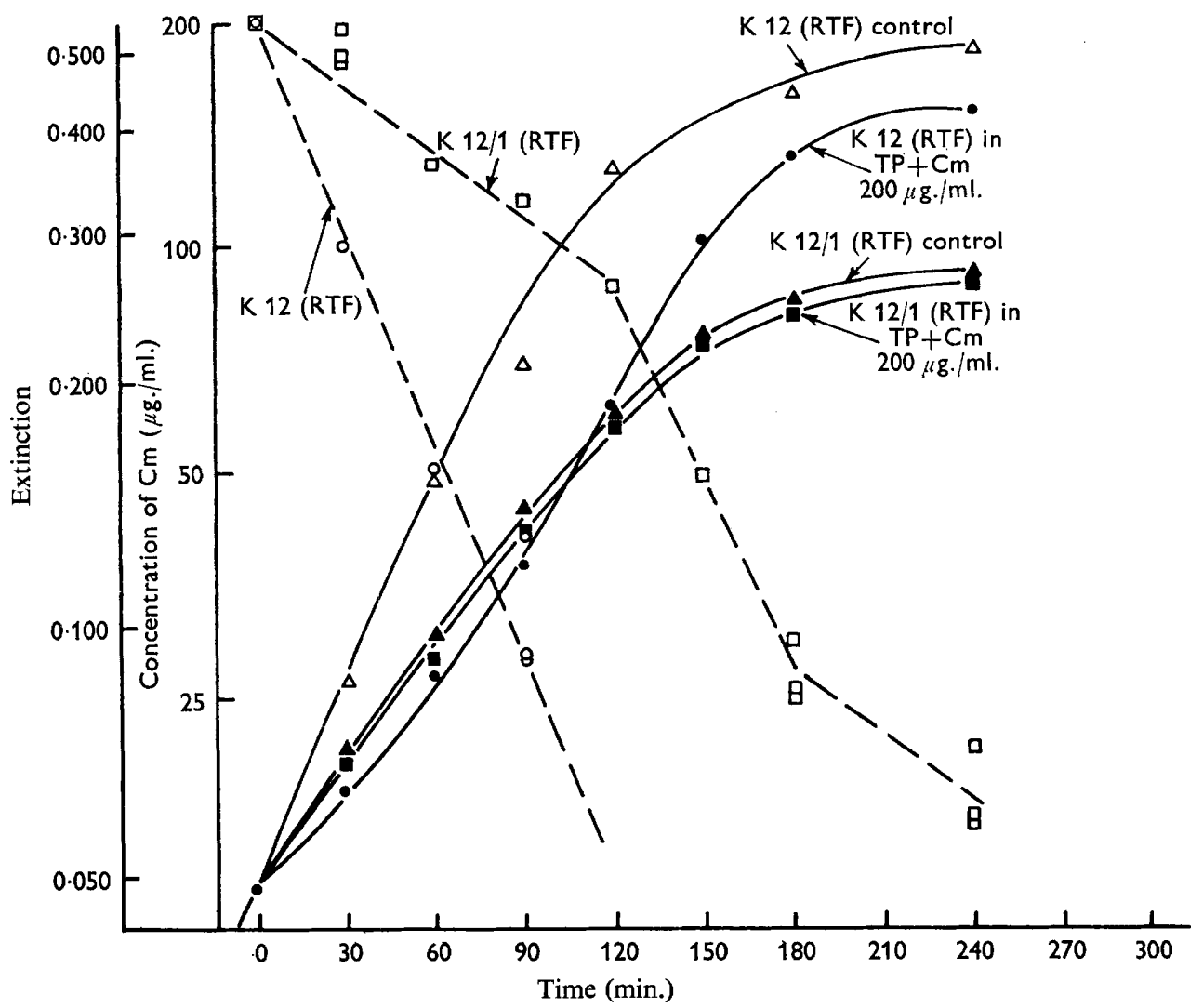

Fig. 5. Inactivation of chloramphenicol and growth in chloramphenicol $(\mathrm{Cm}) 200 \mu \mathrm{g} . / \mathrm{ml}$. in tryptose phosphate (TP) medium by $E$. coli $\mathrm{K} 12$ with resistance transfer factor (RTF) and the tolerant mutant $E$. coli $\mathrm{K} \mathrm{I2/I}$ with the same RTF. Growth of $E$. coli $\mathrm{K}$ I2 (RTF) in TP without $\mathrm{Cm}(\triangle)$ and with $\mathrm{Cm}(\Theta)$. Growth of $E$. coli $\mathrm{K}$ I2/I (RTF) in TP without $\mathrm{Cm}(\Delta)$, and with $\mathrm{Cm}(\square) . \mathrm{O}, \mathrm{Cm}$ by assay in culture of $E$. coli $\mathrm{K} \mathrm{I} 2(\mathrm{RTF}) ; \square, \mathrm{Cm}$ by assay in culture of $E$. coli $\mathrm{K}$ I2/I (RTF). Cm was assayed in samples of the three parallel cultures separately. When any of the values varied more than $\pm 5 \%$ from the mean, all three values are shown; in the other cases only the mean is indicated. The curves for growth in presence of $\mathrm{Cm}$ indicate the mean for three parallel cultures. In no case were the deviations in extinction greater than $5 \%$.

The curves on Fig. 5 show the results of three experiments with Escherichia coli $\mathrm{K} \mathrm{I} 2 / \mathrm{RTF}$ and $E$. coli $\mathrm{K} \mathrm{I2/1/RTF.} \mathrm{Both} \mathrm{strains} \mathrm{were} \mathrm{able} \mathrm{to} \mathrm{grow} \mathrm{in} \mathrm{TP} \mathrm{containing}$ $\mathrm{Cm} 200 \mu \mathrm{g} . / \mathrm{ml}$. Inactivation of $\mathrm{Cm}$ is shown in the figure as a 'semi-log' plot of active $\mathrm{Cm}$ against time. During the first $120 \mathrm{~min}$. after addition of the drug, more than $90 \%$ was inactivated by $E$. coli $\mathrm{K} \mathrm{I} 2 / \mathrm{RTF}$, but only $55 \%$ by the tolerant 


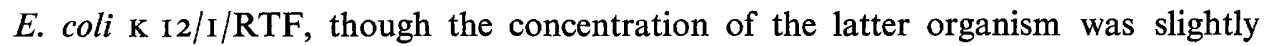
greater than of the former. Similar kinetics of $\mathrm{Cm}$ inactivation by these strains were observed in an experiment with $\mathrm{Cm} 100 \mu \mathrm{g} . / \mathrm{ml}$. As inactivation displays itself intracellularly (Miyamura, I964; and unpublished observation with Shigella flexneri and with $E$. coli B/RTF in our laboratory), it must depend on the rate of uptake.

Uptake of $\left[{ }^{14} \mathrm{C}\right]$ chloramphenicol. Uptake of $\left[{ }^{14} \mathrm{C}\right] \mathrm{Cm}$ was apparently a little higher in Escherichia coli $\mathrm{K} 12$ than in $E$. coli B. The resistant mutant $E$. coli $\mathrm{K}$ I2/I showed a significantly lower radioactivity (I/6) than its ancestor (Table 2).

Cross-resistance to tetracycline. The minimal inhibitory concentration of tetracycline in TPA was raised from I $\mu \mathrm{g}$. $/ \mathrm{ml}$. for the parent strain to $20 \mu \mathrm{g}$. $/ \mathrm{ml}$. for all $22 \mathrm{high}$-level resistant clones of Escherichia coli $\mathrm{K} 12$ which were examined.

\begin{tabular}{|c|c|c|c|c|c|}
\hline $\begin{array}{l}\text { Bacterial } \\
\text { strain }\end{array}$ & Growth rate & $\begin{array}{l}\text { Inactivation } \\
\text { of } \mathrm{Cm}\end{array}$ & Uptake of $\mathrm{Cm}$ & $\begin{array}{l}\text { Effect of } \\
\text { inoculum } \\
\text { size on } \\
\text { resistance }\end{array}$ & $\begin{array}{l}\text { Cross } \\
\text { resistance } \\
\text { to tetra- } \\
\text { cycline }\end{array}$ \\
\hline $\begin{array}{l}\text { E. coli } \mathrm{B} / \mathbf{1} \\
\text { E. coli } \mathrm{K} \mathrm{L} \mathbf{2} / \mathbf{1}\end{array}$ & $\begin{array}{l}\text { As parent strain } \\
\text { Decreased }\end{array}$ & $\begin{array}{l}\text { Yes } \\
\text { No }\end{array}$ & $\begin{array}{l}\text { As parent strain } \\
\text { Decreased }\end{array}$ & $\begin{array}{l}\text { Yes } \\
\text { No }\end{array}$ & $\begin{array}{l}\text { No } \\
\text { Yes }\end{array}$ \\
\hline
\end{tabular}

\section{DISCUSSION}

The main properties of high-level resistant mutants of Escherichia coli $\mathrm{B}$ and $E$. coli $\mathrm{K} \mathrm{I} 2$ are summarized in Table 3. All the observations can be explained by the assumption that in $E$. coli $\mathrm{B}$ resistance is due to inactivation of chloramphenicol, and in $E$. coli $\mathrm{K}$ I 2 to impaired permeability. Inactivation of $\mathrm{Cm}$ by micro-organisms has been reported by several other authors since the first investigation by Smith \& Worrel (1949). Recent publications indicate that an oxidative process requiring acetyl co-enzyme $\mathrm{A}$ is responsible for inactivation in E. coli (Okamoto \& Suzuki, 1965) and in Staphylococcus aureus (Suzuki, Okamoto \& Kono, 1966). The latter authors as well as Miyamura (1964) have presumed that mutants obtained in vitro will never be resistant by virtue of an inactivating ability. Our results with $E$. coli B contradict this. No entirely new enzyme can, of course, be formed by a mutant. Accordingly, this kind of resistance was found only in mutants of $E$. coli B of which the parent strain also proved to inactivate the drug, though to a slight degree. A mutation to an effective degree of inactivation might be one in which the enzyme: (I) is formed in a greater amount; (2) has a higher affinity for the substrate $(\mathrm{Cm}) ;(3)$ is constitutive instead of inducible. It should, however, be pointed out that we have not shown that inactivation of $\mathrm{Cm}$ by the resistant $E$. coli в was due to the same enzymic system as functions to a slow degree in the susceptible ancestor.

One-step mutations to high-level resistance to streptomycin are commonly observed. As far as we are aware, such single-step mutation to high-level resistance to chloramphenicol has hitherto only been reported for Mycobacterium ranae (Szybalski \& Bryson, 1954), but no data are available on the mechanism of resistance in this micro-organism.

In our case it was amply manifested that inactivation was the cause of resistance and not simply a consequence of growth in presence of chloramphenicol, as can be 
seen from the following facts. (I) After addition of $\mathrm{Cm}$ the growth rate was decreased until inactivation was completed (Fig. I). (2) The minimal inhibitory concentration of $\mathrm{Cm}$ depended on the inoculum size. (3) On Cm-containing media an all-or-none growth response occurred (Table I). On the plate with $\mathrm{Cm} 200 \mu \mathrm{g}$. $/ \mathrm{ml}$. TPA, for example, confluent growth was obtained after incubation with $9.0 \times 10^{6}$ bacteria $/ \mathrm{ml}$. This was not due to the ability of a small fraction of the population to form colonies at this $\mathrm{Cm}$ concentration, since no growth occurred when the inoculum size was decreased by only one-tenth.

The inactivating enzymic system must be constitutive because otherwise the chloramphenicol would prevent its synthesis. Further, confirming the report of Merkel \& Steers (I953) that glucose is required for inactivation by non-multiplying bacteria, our results show that inactivation depended on the presence of utilizable carbohydrate. On lactose medium no induction of $\beta$-galactosidase was possible, because of the $\mathrm{Cm}$ present, and without this enzyme no energy source was available for the inactivation. Pre-incubation with lactose unlocked this metabolic knot.

On media containing $\mathrm{Cm} I 00 \mu \mathrm{g} . / \mathrm{ml}$. or more growth depended on very large inoculum sizes; the smallest inoculum which gave growth was 1000 times greater on minimal medium (DA) than on complex TPA medium. Miyamura et al. (I962) reported that small amounts of peptone stimulated inactivation by non-multiplying bacteria. The explanation may be that with an initial high concentration of chloramphenicol virtually all protein synthesis was blocked. $\mathrm{Cm}$-inactivation was therefore limited by the amount of inactivating enzyme present in the sample of bacteria inoculated and co-factors in the bacteria and the nutrient media. On the other hand, with $\mathrm{Cm} 60 \mu \mathrm{g} . / \mathrm{ml}$. each bacterium of the inoculum grew to a colony, indicating that additional enzyme and/or co-factors might be synthesized de novo. This concentration of $\mathrm{Cm}$ may not completely prevent protein synthesis (Okamoto \& Mizuno, 1962).

Uptake of $\left[{ }^{14} \mathrm{C}\right]$ chloramphenicol is generally several times lower in resistant bacteria than in sensitive organisms of the same species (Vazquez, 1964; Unowsky \& Rachmeler, 1966). Our results with Escherichia coli $\mathrm{K} 12$ confirm this; but with Escherichia coli в no difference between the susceptible ancestor and the resistant mutant was noticed. The intracellular concentration of $\mathrm{Cm}$, calculated per wet wt bacteria, was near that of the medium, proving that no concentration of $\mathrm{Cm}$ occurred. It follows from this that entry to, inactivation, and exit from the cell of $\mathrm{Cm}$ molecules must occur at a great rate. From Fig. 2 it can be seen that $1.5 \times 10^{8}$ bacteria ( $\mathrm{I}$ ml. at a concentration corresponding to 22 Klett units) inactivated $300 \mu \mathrm{g}$. $\mathrm{Cm}$, which is $5.6 \times 10^{17}$ molecules $\mathrm{Cm} / 30 \mathrm{~min}$. or $2.54 \times 10^{6} \mathrm{molecules} / \mathrm{bacterium} / \mathrm{sec}$.

Hitherto we have not isolated mutants of the chloramphenicol-tolerant kind from Escherichia coli $\mathrm{B}$, in spite of the fact that many mutant clones have been examined. With $E$. coli $\mathrm{K} \mathrm{I2}$, of which 36 mutants were examined, not one $\mathrm{Cm}$ inactivator was found. Decreased permeability to $\mathrm{Cm}$ was found in mutants of the latter variant of $E$. coli. That resistance was due to this lowered permeability was shown by the complete inhibition of growth after an incubation period in a $\mathrm{Cm}$-containing buffer solution.

The decreased permeability may be non-specific for $\mathrm{Cm}$. Cross-resistance with tetracycline and puromycin (Reeve \& Bishop, 1965) should not uncritically be related to common features in the action of these three antibiotics. It might well be a consequence of decreased permeability for a wide range of micromolecular species. The 
markedly decreased growth rate in TP medium as well as in minimal medium might simply be a consequence of an unspecific permeability barrier.

The growth curve of the resistant mutant Escherichia coli $\mathrm{K} \mathrm{I2/1}$ in TP medium (Fig. 3) indicates that there must have been something more than a simple decrease in the rate of permeation, since growth ceased at a much lower population density than for the sensitive strain.

The practical aspect of resistance to chloramphenicol is outside the scope of this communication. It may, however, be mentioned that inactivation is a far more serious form of drug resistance than is the mechanism observed with $E$. coli $\mathrm{K} \mathrm{I} 2$, which places the micro-organism in absence of the drug at a competitive disadvantage.

Mr Keizman from Abic Ltd., Ramat Gan, generously provided us with the chloramphenicol used. Dr R. Rozansky, Director of the Bacteriological Department, Tel Aviv municipal hospitals, Dr E. Vure, Director of Pediatric Department C, and Dr René Schmidt, from the rehabilitation centre, Assaf Harofe Government Hospital, Zrifin, have provided helpful criticism in preparation of the manuscript. Mrs Ruth ZieglerSchlomovicz, B.Sc., co-operated skilfully in some of this work. A part of this study was supported by research grant 64/3/32 from Bar Ilan University.

\section{REFERENCES}

Cavalli, L. L. \& Maccacaro, G. A. (I952). Polygenic inheritance of drug-resistance in the bacterium, Escherichia coli. Hereditary 6, $3 \mathrm{II}$.

Chabbert, Y. \& Debruge, J. (I956). La résistance naturelle de staphylocoques au chloramphenicol. Annls. Inst. Pasteur, Paris 91, 225.

Davis, B. D. \& Mingioli, E. S. (I950). Mutants of Escherichia coli requiring methionine or $\mathbf{B}_{12}$. J. Bact. 60, 17.

Dunsmoor, C. L., Pin, K. L. \& Sherris, I. C. (1963). Observations on the inactivation of chloramphenicol by chloramphenicol resistant staphylococci. Antimicrob. Ag. Chemother. p. 500.

LURIA, S. E. \& DELBRÜCK, M. (I943). Mutations of bacteria from virus sensitivity to virus resistance. Genetics 28, 49I.

MERKel, J. R. \& STEERs, E. (1953). Relationship between chloramphenicol reductase activity and chloramphenicol resistance in E. coli. J. Bact. 66, 389.

MrYamuRA, S. (1964). Inactivation of chloramphenicol by chloramphenicol resistant bacteria. J. pharm. Sci. 53, 604 .

Miyamura, S., Oketant, S., Shigeno, N. \& Watanabe, T. (1962). Chloramphenicol inactivation by microorganisms. III. The action of resistant Escherichia coli on chloramphenicol. Jap. J. Bact. 17, 787. After: Excerpta med. Sect. 4, 1963, 16, no. 3212.

Oкамото, S. \& Mizuno, D. (I962). Inhibition by chloramphenicol of protein synthesis in the cell free system of a chloramphenicol resistant strain of $E$. coli. Nature, Lond. 195, IO22.

Oкамото, S. \& Mizuno, D. (1964). Mechanism of chloramphenicol and tetracycline resistance in Escherichia coli. J. gen. Microbiol. 35, 125.

OKAмото, S. \& SuzukI, J. (1965). Chloramphenicol, dihydrostreptomycin and kanamycin. Inactivating enzyme from multiple drug resistant $E$. coli carrying episome 'R'. Nature, Lond. 208, 1301.

RAMSEY, H. H. (1958). Protein synthesis as a basis for chloramphenicol resistance in Staphylococcus aureus. Nature, Lond. 182, 602.

Rananarayna, B., Rayaulakshmi, M. R. \& Ehaskaran, C. S. (I962). Resistance of Salmonella typhi to chloramphenicol. J. clin. Path. 15, 544.

ReEve, E. C. R. \& Bishop, J. O. (1965). Multistep resistance to chloramphenicol in RC-stringent Escherichia coli $\mathrm{K}$ I2-its effect on the induction of RNA synthesis by antibiotics under amino acid starvation. Genet. Res. 6, 304.

Smith, G. N. \& Worrel, C. S. (1949). Enzymatic reduction of chloramphenicol. Archs Biochem. 24, 216.

SuZUKI, Y., Окамото, S. \& Kono, M. (I966). Basis of chloramphenicol resistance in naturally isolated resistant staphylococci. J. Bact. $\mathbf{9 2 ,} 798$.

5

G. Microb. 50 
SZYBaLSKI, W. \& Bryson, V. (I954). Genetic studies on microbial cross resistance to toxic agents. III. Cross resistance of Mycobacterium ranae to twenty-eight antimycobacterial agents. Am. Rev. Tuberc. 69, 267.

UNOWSKY, J. \& RACHMELER, M. (I966). Mechanism of antibiotic resistance determined by resistancetransfer factors. J. Bact. 92, 358.

VAZQUEZ, D. (1963). Antibiotics which affect protein synthesis. The uptake of $\mathrm{C}^{14}$ chloramphenicol by bacteria. Biochem. biophys. Res. Commun. 12, 409.

VAZQUEZ, D. (1964). Uptake and binding of chloramphenicol by sensitive and resistant organisms. Nature, Lond. 203, 257.

Watanabe, T. \& FuKasawa, T. (I96I). Episome mediated transfer of drug resistance in Enterobacteriaceae. I. Transfer of resistance factor by conjugation. J. Bact. 81, 669 . 